\title{
The Charter of Whiteness: Twenty-Five Years of Maintaining Racial Injustice in the Canadian Criminal Justice System
}

David M. Tanovich

Follow this and additional works at: http://digitalcommons.osgoode.yorku.ca/sclr

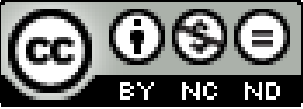

This work is licensed under a Creative Commons Attribution-Noncommercial-No Derivative Works 4.0 License.

\section{Citation Information}

Tanovich, David M.. "The Charter of Whiteness: Twenty-Five Years of Maintaining Racial Injustice in the Canadian Criminal Justice System." The Supreme Court Law Review: Osgoode's Annual Constitutional Cases Conference 40. (2008).

http://digitalcommons.osgoode.yorku.ca/sclr/vol40/iss1/21 


\title{
The Charter of Whiteness: Twenty-Five Years of Maintaining Racial Injustice in the Canadian Criminal Justice System
}

\author{
David M. Tanovich*
}

Racism, and in particular anti-black racism, is a part of our community's psyche. A significant segment of our community holds overtly racist views. A much larger segment subconsciously operates on the basis of negative racial stereotypes. Furthermore, our institutions, including the criminal justice system, reflect and perpetuate those negative stereotypes. These elements combine to infect our society as a whole with the evil of racism. Blacks are among the primary victims of that evil.

R. v. Parks, [1993] O.J. No. 2157, 84 C.C.C. (3d) 353, at 369

(Ont. C.A.), Doherty J.A.

Aboriginal people are overrepresented in virtually all aspects of the [criminal justice] system. As this Court ... noted in R. v. Williams ... there is widespread bias against aboriginal people within Canada, and "[t]here is evidence that this widespread racism has translated into systemic discrimination in the criminal justice system." ... The figures are stark and reflect what may fairly be termed a crisis in the Canadian criminal justice system. ... The unbalanced ratio of imprisonment for aboriginal offenders flows from a number of sources ... [including] bias against aboriginal people and from an unfortunate institutional approach that is more inclined to refuse bail and to impose more and longer prison terms for aboriginal offenders.

R. v. Gladue, [1999] S.C.J. No. 19, [1999] 1 S.C.R. 688, at paras. 61, 64-65 (S.C.C.), Cory and Iacobucci JJ.

The community at large and the courts, in particular, have come, some would say belatedly, to recognize that racism operates in the criminal justice system ... With this recognition has come an acceptance by the

\footnotetext{
of Ontario and the research assistance of Jillian Rogin, a third-year law student.
}

Faculty of Law, University of Windsor. I wish to thank the funding of the Law Foundation 
courts that racial profiling occurs and is a day-to-day reality in the lives of those minorities affected by it.

Peart v. Peel Regional Police Services Board, [2006] O.J. No. 4457, 43 C.R. (6th) 175, at para. 94 (Ont. C.A.), Doherty J.A.

\section{INTRODUCTION}

As we reflect on the 25-year anniversary of the Canadian Charter of Rights and Freedoms, ${ }^{1}$ much will be written about the impact this constitutional document has had on those living at the margins. While no sweeping generalizations are possible when dealing with such complex issues, it is fair to say that some groups such as women and gays and lesbians can point to a number of significant victories ranging from the right of reproductive choice to the right to same-sex marriage. Can the same be said of racial injustice in the criminal justice system? The manifestations of this injustice include over- and under-policing, discriminatory bail, trial and sentencing outcomes, and mass incarceration. They have been well documented in study after study over the last 20 years. ${ }^{2}$ Has the Charter given any hope to Aboriginal and racialized communities that fundamental justice is possible?

This paper's thesis is that while there is reason to be optimistic about the possibilities for future reform, the Charter has, to date, had very little impact on racial injustice in Canada. We continue to incarcerate

\footnotetext{
1 Part I of the Constitution Act, 1982, being Schedule B to the Canada Act (U.K.), 1982, c. 11 [hereinafter "the Charter"].

2 See Report of the Ipperwash Inquiry (Toronto: Queen's Printer, 2007); Stolen Sisters: A Human Rights Response to Discrimination and Violence Against Indigenous Women in Canada (Ottawa: Amnesty International Canada, 2004); Report of the Commission of Inquiry into Matters Relating to the Death of Neil Stonechild (Regina: Queen's Printer, 2004); Legacy of Hope: An Agenda for Change (Final Report from the Commission on First Nations and Metis People and Justice Reform) (Regina: Queen's Printer, 2004); Paying the Price: The Human Cost of Racial Profiling (Toronto: Ontario Human Rights Commission, 2003); Bridging the Cultural Divide: A Report on Aboriginal People and Criminal Justice in Canada (Ottawa: Minister of Supply and Services, 1996); Report of the Commission on Systemic Racism in the Ontario Criminal Justice System (Toronto: Queen's Printer, 1995); Report of the Aboriginal Justice Inquiry of Manitoba: The Justice System and Aboriginal People (Volume 1) and The Deaths of Helen Betty Osbourne and John Joseph Harper (Volume 2) (Winnipeg, Queen's Printer, 1991); Justice on Trial: Report of the Task Force on the Canadian Criminal Justice System and its Impact on the Indian and Metis People of Alberta (Edmonton: The Task Force, 1991); Aboriginal Peoples and Criminal Justice, Report No. 34 (Minister's Reference) (Ottawa: Law Reform Commission of Canada, 1991); Findings and Recommendations of the Royal Commission on the Donald Marshall, Jr., Prosecution (Halifax: The Royal Commission 1989); Final Report: Task Force on Aboriginal Peoples in Federal Corrections (Ottawa: Supply and Services, 1989).
} 
Aboriginals and African Canadians at alarming rates, ${ }^{3}$ racial profiling at our borders and in our streets continues to flourish, ${ }^{4}$ and the federal government continues to propose legislation that will further entrench the problem. ${ }^{5}$ Of course, some might say that it is simply naive to think that the Charter can make a difference and so Part II of the paper briefly addresses this larger philosophical question. In Part III, the paper explores why it is not the Charter that is the problem, but rather those who apply and interpret it. Racial justice has not had a chance to grow over the last 25 years because there has been a significant failure of trial and appellate lawyers to engage in race talk in the courts and a failure of the judiciary to adopt appropriate critical race standards when invited to do so.

The discussion is not meant to criticize or to lay blame but rather to show just how many opportunities we have had to make meaningful reform in this area over the life of the Charter. The message is one of hope for what is possible with the appropriate calibration and imagination. The paper is also, in many respects, a response to Justice Michael Moldaver's state of the criminal union and, in particular, his belief that "[m]any of the Charter issues that you are likely to encounter on a dayto-day basis have been thoroughly litigated, all the way to the Supreme Court of Canada. By and large, the governing principles are now firmly established." Nothing could be further from the truth when it comes to race-based Charter litigation.

\section{The UTILITY OF USING LITIGATION TO ADDRESS RACIAL INJUSTICE IN THE CRIMINAL JUSTICE SYSTEM}

As noted earlier, some may argue that the central question being explored here is a doomed one because it assumes that Charter litigation can bring about real change. Oppression is far too deeply rooted, the argument goes, to expect a document focused on individual rights and

3 See Jonathan Rudin, “Aboriginal Peoples and the Criminal Justice System" (Research Paper Commissioned by the Ipperwash Inquiry) online: (The Ipperwash Inquiry) < http://www. ipperwashinquiry.ca/policy_part/research/index.html> (date accessed: March 7, 2008).

4 See David M. Tanovich, The Colour of Justice: Policing Race in Canada (Toronto: Irwin Law, 2006), at chapters 4-7.

5 See, for example, Bill C-2, the Tackling Violent Crime Act, S.C. 2008, c. 6.

6 See Michael Moldaver, "Long Criminal Trials: Masters of a System They Are Meant to Serve" (2005) 32 C.R. (6th) 316. For criticisms of Moldaver's thesis, see Don Stuart, "The Charter Is a Vital Living Tree and Not a Weed to Be Stunted — Justice Moldaver Has Overstated" (2006) 40 C.R. (6th) 280; James Stribopoulos, "Has Everything Been Decided? Certainty, the Charter and Criminal Justice" (2006) 34 S.C.L.R (2d) 381. 
applied by largely White middle-class judges to make any meaningful structural change. ${ }^{7}$ And while it is true that there have been significant Charter victories for some marginalized groups, these critics would likely respond that they are largely symbolic in nature, resulting in little or no real change. What good is it, for example, to recognize same-sex marriage and then permit homophobic state and religious officials to refuse to perform marriage ceremonies?

There is much truth to these responses and there is no question that litigation as a political strategy for reform has a number of inherent limitations. ${ }^{8}$ However, successful litigation brings with it, in addition to the individual and systemic remedies fashioned, considerable attention, whether it be in the media, community organizations, universities and law schools, or at judicial conferences. This can help to raise public consciousness, stimulate academic research ${ }^{9}$ and teaching, ${ }^{10}$ and mobilize

There is also the argument that the criminal justice system itself is so inherently flawed that it is incapable, no matter the scope of the reform, of respecting Aboriginal conceptions of justice. See Patricia Monture-Angus, Thunder in My Soul: A Mohawk Woman Speaks (Halifax: Fernwood Publishing, 1995), at chapter 12. This broad and complex philosophical question is well beyond the scope of this paper and will not be addressed. See also H.S. LaForme, "The Justice System in Canada: Does it Work for Aboriginal People?" (2005) 4 Indigenous L.J. 1.

8 For a critical discussion of using litigation to stimulate social change, see W.A. Bogart, Courts and Country: The Limits of Litigation and the Social and Political Life of Canada (Toronto: Oxford University Press, 1994); Kent Roach, Due Process and Victims' Rights: The New Law and Politics of Criminal Justice (Toronto: University of Toronto Press, 1999); Christopher Manfredi, Feminist Activism in the Supreme Court: Legal Mobilization and the Women's Legal Education and Action Fund (Vancouver: UBC Press, 2004); Michael McCann, Rights at Work: Pay Equity Reform and the Politics of Legal Mobilization (Chicago: University of Chicago Press, 1994); Gerald N. Rosenberg, The Hollow Hope: Can Courts Bring About Social Change? (Chicago: University of Chicago Press, 1993).

9 Outside of the work of Scot Wortley, a criminologist at the University of Toronto, there is very little empirical work being conducted in Canada on systemic racism in the criminal justice system, particularly in Western Canada. For a discussion of Wortley's work, see David M. Tanovich, The Colour of Justice: Policing Race in Canada (Toronto: Irwin Law, 2006), at 75-76.

10 Currently, there are relatively few critical race theory or practice courses at Canadian law schools. We are, however, beginning to see the issue of the Charter, race and criminal justice becoming more prominent in the Canadian academic literature. See, for example, David M. Tanovich, The Colour of Justice: Policing Race in Canada (Toronto: Irwin Law, 2006); Kent Roach, Due Process and Victims' Rights: The New Law and Politics of Criminal Justice (University of Toronto Press, 1999), at chapters 7 and 8; Don Stuart, Charter Justice in Canadian Criminal Law, 4th ed. (Toronto: Thomson Carswell, 2005), at 250, 314-18, 415-16, 418, 497-99; Tim Quigley, Procedure in Canadian Criminal Law, $2 \mathrm{~d}$ ed. (Toronto: Thomson Carswell, 2005) at 6-6 - 6-10; 9-17, 11-3. While these authors have explored the intersection of a number of Charter rights and racism, there are other academics and commentators who have explored the issue in relation to particular rights, most often in relation to section 9. See, for example, James Stribopoulos, "The Limits of Judicially Created Police Powers: Investigative Detention After Mann" (2007) 52 Crim. L.Q. 299; Benjamin Berger, "Race and Erasure in R. v. Mann (2004) 21 C.R. (6th) 58. With respect to other legal rights, see Christine Boyle, "Annotation to R. v. Law (2002) 48 C.R. (5th) 199; Sujit 
political action. One of the most important political responses could be the collection of data which will reveal the extent and scope of racial injustice in policing and other facets of the system. ${ }^{11}$

Moreover, the idea that the democratic or the legislative process will bring anti-racist change to the criminal justice system is sheer folly. There is no evidence over the last decade that it will ever occur given the increased politicization of crime and unconscious nature of systemic racism. ${ }^{12}$ As Professor Stuart has noted, "[p]oliticians of all stripes have been unable to resist the political expediency of pandering to the perceived need to toughen penal responses. There are no votes in being soft on crime." ${ }^{\prime 3}$ The absence of any racial profiling legislation either

Choudhry \& Kent Roach, "Racial and Ethnic Profiling: Statutory Discretion, Constitutional Remedies and Democratic Accountability" (2003) 41 Osgoode Hall L.J. 1; Diana Lumba, "Deterring Racial Profiling: Can Section 24(2) of the Charter Realize Its Potential?" (2006) 22 Windsor Rev.Legal \& Soc. Issues 79; Faizal Mirza, "Examining Racism and Criminal Justice: The Advancement of a Defence Based on Section 15(1) of the Canadian Charter of Rights and Freedoms" in Camille Nelson \& Charmaine Nelson, eds., Racism, Eh? A Critical Inter-Disciplinary Anthology of Race and Racism in Canada (Concord: Captus Press, 2004), at chapter 5; Larry Chartrand, "Aboriginal Peoples and Mandatory Sentencing" (2001) 39 Osgoode Hall L.J. 449; Faizal Mirza, "Mandatory Minimum Prison Sentencing and Systemic Racism" (2001) 39 Osgoode Hall L.J. 491; Cynthia Peterson, "Institutionalized Racism: The Need for Reform of the Criminal Jury Selection Process" (1993) 38 McGill L.J. 147.

11 See Policy and Guidelines on Racism and Racial Discrimination (Ontario Human Rights Commission, 2005), at 44-48; David M. Tanovich, The Colour of Justice: Policing Race in Canada (Toronto: Irwin Law, 2006), at 173-77. See further Andrew Taslitz, "Racial Auditors and the Fourth Amendment: Data with the Power to Inspire Political Action" (2003) 66 Law \& Contemp. Probs. 221; David Harris, "The Reality of Racial Disparity in Criminal Justice: The Significance of Data Collection” (2003) 66 Law \& Contemp. Probs. 71.

12 The only example of a non-punitive anti-racist approach to criminal justice is section 718.2(e) of the Criminal Code, R.S.C. 1985, c. C-46, enacted in 1996. The initiative was part of Bill C-46, Canada's first comprehensive sentencing legislation, which was primarily aimed at reducing the reliance on imprisonment in Canada. Section 718.2(e) demands that judges pay particular attention to the lived experience of Aboriginal offenders when sentencing them. See $R$. v. Gladue, [1999] S.C.J. No. 19, [1999] 1 S.C.R. 688 (S.C.C.). The provision, however, has had little impact in addressing the problem. For a discussion of some of the structural and procedural reforms necessary to ensure greater effectiveness, see Jonathan Rudin, "Aboriginal Peoples and the Criminal Justice System" (Research Paper Commissioned by the Ipperwash Inquiry) online: (The Ipperwash Inquiry) <http://www.ipperwashinquiry.ca/policy_part/research/index.html> (date accessed: March 7, 2008), at 47-68. In R. v. Borde, [2003] O.J. No. 354, 172 C.C.C. (3d) 225 (Ont. C.A.), the Ontario Court of Appeal held that a similar approach should be applied when sentencing African Canadian offenders. But see R. v. Hamilton, [2004] O.J. No. 3252, 186 C.C.C. (3d) 129 (Ont. C.A.) which has limited Borde's application in drug cases. See further the discussion in Dale Ives, "Inequality, Crime and Sentencing: Borde, Hamilton and the Relevance of Social Disadvantage in Canadian Sentencing Law" (2004) 30 Queen's L.J. 114.

13 See Don Stuart, Charter Justice in Canadian Criminal Law, 4th ed. (Toronto: Thomson Carswell, 2005), at 14-16. See also Kent Roach, Due Process and Victims' Rights: The New Law and Politics of Criminal Justice (University of Toronto Press, 1999), where Professor Roach points out that one of the reasons that women have had so much success in bringing about criminal law 
provincially or federally, ${ }^{14}$ the passing of the Anti-Terrorism Act by the Liberal government ${ }^{15}$ and the recent package of Conservative Criminal $\operatorname{Code}^{16}$ amendments which, among other initiatives, add new and increased mandatory minimums for gun offences, ${ }^{17}$ are just a few examples. All of these initiatives have had and will have a disproportionate impact on racialized communities.

And so, Charter litigation remains an important means of addressing fundamental injustice. In theory, it should have a significant impact. This is especially true with respect to racial injustice in the criminal justice system because of the inexorable ties between the rights and freedoms guaranteed under the Charter and the criminal justice system. ${ }^{18}$ The legal rights in sections 7-15 and the remedial provision that is section 24 are the most litigated Charter rights and the litigation is occurring in the criminal context because of access and motivation. As a general rule, accused have access to the courts to launch a Charter challenge by virtue of access to state-funded legal counsel. And, of course, one would expect that accused are motivated to argue all live issues. This is why it is often said that criminal accused act as surrogate litigants to ensure that civil liberties and human rights are respected by the state. Indeed, as a result of the racialized litigants who were successful in $R$. v. Khan, ${ }^{19} R$. v.

reform in the area of sexual assault is precisely because it permitted the government to promote its crime control agenda, an agenda that remains popular on election day.

14 Libby Davies has twice attempted to introduce a racial profiling private member's bill (An Act to Eliminate Racial Profiling) in the House of Commons with no success. See David M. Tanovich, The Colour of Justice: Policing Race in Canada (Toronto: Irwin Law, 2006), at 172.

15 See Bill C-36, An Act to amend the Criminal Code, the Official Secrets Act, the Canada Evidence Act, the Proceeds of Crime (Money Laundering) Act and other Acts, and to enact measures respecting the registration of charities, in order to combat terrorism, 1st Sess., 37th Parl., 2001, S.C. 2001, c. 41. Bill C-36 received Royal Assent on December 18, 2001 and came into force on December 24, 2001. The Act is scheduled to receive a facelift from the Conservative government given that the five-year sunset clause has now expired on two of the Act's powers (i.e., investigative hearings and preventative arrest) and the motive clause was struck down: $R$. v. Khawaja, [2006] O.J. No. 4245, 214 C.C.C. (3d) 399 (Ont. S.C.J.). In addition, in Charkaoui v. Canada (Citizenship and Immigration), [2007] S.C.J. No. 9, [2007] 1 S.C.R. 350 (S.C.C.), the Supreme Court struck down the security certificate regime in the Immigration and Refugee Protection Act, S.C. 2001, c. 27.

16 R.S.C. 1985 , c. C-46.

17 See Bill C-2: Tackling Violent Crime Act, S.C. 2008, c. 6 (Royal Assent February 28, 2008). Other initiatives include removing personal violent offences from conditional sentence eligibility (see Bill C-9: An Act to amend the Criminal Code (conditional sentence of imprisonment), S.C. 2007, c. 12. Bill C-9 received Royal Assent on May 31, 2007 and came into force six months from that date.

18 See Carol Aylward, Canadian Critical Race Theory: Racism and the Law (Halifax: Fernwood, 1999).

19 [2004] O.J. No. 3819, 189 C.C.C. (3d) 49 (Ont. S.C.J.). 
Brown, ${ }^{20} R$. v. Campbell ${ }^{21}$ and $R$. v. Nguyen, ${ }^{22}$ we are beginning to see, at least in the context of racial profiling, a greater number of human rights and civil cases where individuals not found with contraband are challenging the conduct of the police. Substantial damages and systemic remedies have been imposed in successful cases. ${ }^{23}$

Moreover, while systemic racism is present in all social systems, one can reasonably argue that some of the most harmful and lasting effects of racial injustice are caused by the criminal justice system. The collateral effects of over-incarceration and constant surveillance (e.g., racial profiling) on racialized communities are enormous and now well documented. ${ }^{24}$ They include physical and severe psychological harm (in some cases death), isolation, alienation and mistrust, behaviour changes, breakdown of or damage to family and social networks, and labour market exclusion. ${ }^{25}$ Indeed, in many ways, colonialism, slavery and

20 [2003] O.J. No. 1251, 173 C.C.C. (3d) 23 (Ont. C.A.)

21 [2005] Q.J. No. 394 (C.Q.).

22 [2006] O.J. No. 272 (Ont. S.C.J.). See also R. v. Nguyen, [2006] O.J. No. 1221 (Ont. C.J.); R. v. Mac, [2005] O.J. No. 527 (Ont. S.C.J.).

23 See most notably, Nassiah v. Peel Regional Police Services Board, [2007] O.H.R.T.D. No. 14 (O.H.R.T.) (\$20,000); "Three [Montreal] Transit Guards Found Guilty of Racial Profiling" The Gazette (15 July 2006) (\$15,000); Radek v. Henderson Development (Canada) Ltd., [2005] B.C.H.R.T.D. No. 302 (B.C.H.R.T.) (\$5,000); Johnson v. Halifax (Regional Municipality) Police Service, [2003] N.S.H.R.B.I.D. No. $2(\$ 10,000)$ (N.S.H.R.B.I.). There are a number of other cases pending before both the Ontario and Quebec Human Rights Commissions.

24 The extent of the incarceration crisis in the African Canadian and Aboriginal communities is evident from 1992/1993 data from Ontario which show that African Canadians accounted for 60 per cent of admissions to provincial institutions in Metropolitan Toronto for drug trafficking/importing offences, and from 2001 data which reveal that Aboriginals made up 77 per cent, 69 per cent and 38 per cent of offenders in Saskatchewan, Manitoba and Alberta correctional facilities. See David M. Tanovich, The Colour of Justice: Policing Race in Canada (Toronto: Irwin Law, 2006), at 88-89 and Jonathan Rudin, "Aboriginal Peoples and the Criminal Justice System" (Research Paper Commissioned by the Ipperwash Inquiry) online: (The Ipperwash Inquiry) <http://www. ipperwashinquiry.ca/policy_part/research/index.html> (date accessed: March 7, 2008), at 14. In the federal system (2005-2006), Aboriginals made up 18.7 per cent of incarcerated offenders, while Aboriginal women made up 31.4 per cent of women offenders who are incarcerated. See "Corrections and Conditional Release Statistical Overview - 2006", online: Public Safety Canada, <http://www.publicsafety.gc.ca/res/cor/rep/cprmindex-en.asp> (date accessed: 2 September 2007). In 2002, Aboriginals constituted 21 per cent of all individuals in prison across Canada. See "Aboriginal Peoples and the Criminal Justice System", at 14.

25 See, for example, the discussion in Paying the Price: The Human Cost of Racial Profiling (Toronto: Ontario Human Rights Commission, 2003), at 16-66; Dorothy E. Roberts, "The Social and Moral Cost of Mass Incarceration in African American Communities" (2004) 56 Stan. L. Rev. 1271; Marc Mauer \& Meda Chesney-Lind, eds., Introduction to Invisible Punishment: The Collateral Consequences of Mass Incarceration (New York: The New Press, 2003); Gabriel Chin, "Race, the War on Drugs, and the Collateral Consequences of Criminal Conviction" (2002) 6 J. Gender Race \& Just. 253; Dorothy E. Roberts, "Criminal Justice and Black Families: The Collateral Damage of Over-Enforcement” (2001) 34 U.C. Davis L. Rev. 1005. 
segregation are now reproduced through both of these modern-day systems of control and incapacitation.

While I place considerable reliance on Charter litigation to address racial injustice, there is no question that other legal and extra-legal strategies are necessary in order to ensure implementation of the changes and to fill in the gaps when litigation fails. Anti-racist training for all criminal justice actors, the creation of monitoring systems, the creation of more anti-racist actors such as Gladue workers (i.e., those who prepare sentencing reports for Aboriginal offenders), the appointment of more Aboriginal and racialized judges, greater funding for community programs, community mobilization and political lobbying are all examples of strategies that can work together with litigation. Having tried to justify a call for more and enhanced use of the Charter, the paper now moves to an exploration of how it is that a "Charter of Whiteness" has been created.

\section{The Problem Is Not WITH THE CHARTER BUT WITH THOSE WHo ARGUE AND INTERPRET IT}

\section{Adjudication and the Failure to Act}

Narrow approaches to judicial review and lack of judicial imagination have played a role in limiting the impact of Charter litigation on racial injustice. In a number of key cases addressing issues such as bail, jury selection and racial profiling, courts have refused to adopt critical race standards or arguments when they were advanced. Some of these cases include:

- $\quad$ R. v. Laws $^{26}$ - The accused argued that the citizenship requirement for jury duty in section 2 of the Juries $A c t^{27}$ violated section 15(1) because it had a disproportionate impact on African Canadians. The argument was rejected on narrow and statistical grounds. There was evidence led at the trial in 1993 that 34.1 per cent of the Black residents of Toronto are non-citizens while only 14.4 per cent of the non-Black residents are non-citizens. There was additional evidence that if the citizenship requirement in the Juries Act were removed the probability of choosing a Black person on the jury would increase from 3.2 in 100 to 4.1 in 100, representing an increase of 0.9 per cent. The Court of Appeal held that:

\footnotetext{
26 [1998] O.J. No. 3623, 128 C.C.C. (3d) 516 (Ont. C.A.).

27 R.S.O. 1990, c. J.3.
} 
In light of the Parks/Williams challenge for cause and other safeguards to ensure trial fairness, the slight statistical advantage to a black accused of permitting non-citizens to serve on a jury does not constitute an advantage for the purposes of s. 15. The inclusion of non-citizens would not materially increase the possibility that a black juror will in fact end up on the jury, bearing in mind that the statistical probability of choosing a black person on the jury is increased by less than $1 \%$. The burden was on the appellant to show that he was deprived of a real benefit or advantage. He does not meet that burden by merely pointing to these statistics. We are unable to draw the inference that this statistical probability would materially enhance trial fairness for the appellant or any other black accused. ${ }^{28}$

The Court did not address the concerns expressed by the Ontario Systemic Racism Commission that the "main systemic barriers to participation of black and other racialized people on trial juries appear to be the citizenship qualification and the database used to list the names from which jurors are selected" and that "citizenship restriction for jurors seems particularly anomalous since no such restriction applies to justices of the peace, lawyers, or judges, all of whom are familiar with community standards." Nor did the Court consider the Commission's recommendation that "... the Juries Act be amended to permit landed immigrants to serve as jurors if they have lived in Canada for three years and are otherwise eligible., ${ }^{29}$

The Court also did not consider the broader section 15(1) argument that there is a miscarriage of justice any time a key element of the trial process is implicated in racial discrimination. It was arguably able to avoid dealing with this broader argument by its previous decision in $R$. v. Church of Scientology of Toronto ${ }^{30}$ that an accused had no standing to use section 15(1) to argue that the equality rights

28 [1998] O.J. No. 3623, 128 C.C.C. (3d) 516, at 540 (Ont. C.A.).

29 See Report of the Commission on Systemic Racism in the Ontario Criminal Justice System (Toronto: Queen's Printer, 1995), at 250-52. The problem surrounding the lack of Aboriginal and racialized jurors on Canadian juries is discussed in Cynthia Peterson, "Institutionalized Racism: The Need for Reform of the Criminal Jury Selection Process" (1993) 38 McGill L.J. 147.

30 [1997] O.J. No. 1548, 116 C.C.C. (3d) 1, at 51-56 (Ont. C.A.). 
of a prospective juror, in this case a racialized non-citizen, were violated. ${ }^{31}$

- $\quad$ R. v. Hall B $^{2}$ - The Criminal Lawyers' Association of Ontario ("CLA"), relying on the empirical work of the Ontario Systemic Racism Commission, made substantial submissions on the impact of race on bail decisions in a Charter section 11(f) constitutional challenge to section 515(10)(c) of the Criminal Code. ${ }^{33}$ This section gives broad discretion to justices of the peace to detain accused who are not a danger or flight risk, but where a determination is made that denial of bail is necessary to maintain confidence in the administration of justice. The Commission had found the following racial disparities in pre-trial detention decisions:

- White accused were more likely to be released by the police or not detained following a bail hearing than Black accused.

- White accused were treated more favourably even though they were more likely than Black accused to have a criminal record and to have a more serious record.

- In drug cases, White accused were twice as likely to be released by the police than Black accused. Black accused were three times more likely to be denied bail than White accused.

- Employment status accounted for some of the racial inequality in imprisonment before trial, but it does not fully explain the disparities.

It thus concluded that "some black accused who were imprisoned before trial would not have been jailed if they had been white, and some white accused who were freed before trial would have been

31 This narrow approach to standing is criticized in David M. Tanovich, David M. Paciocco \& Steven Skurka, Jury Selection in Criminal Trials: Skills, Science and the Law (Toronto: Irwin Law, 1997), at 21-26.

32 [2002] S.C.J. No. 65, [2002] 3 S.C.R. 309 (S.C.C.).

33 R.S.C. 1985 , c. C-46. 
detained had they been black." ${ }^{34}$ The CLA submissions were not considered in either the majority or dissenting opinions. ${ }^{35}$

- R. v. Pan; R. v. Sawyer ${ }^{36}$ - Sawyer, who is White, was tried together with Galbraith, who is Black, on a charge of assault. Following the conviction, a juror contacted Sawyer and told him that she had been under "undue pressure to come to a verdict and that certain racial comments were made by other members of the jury". The accused argued that the common law jury secrecy rule needed to be altered under section 7 of the Charter to ensure that verdicts were not tainted by racism. The argument was rejected.

- $\quad$ R. v. Gayle $e^{37}$ - The accused argued that the trial judge had erred in not expanding the scope of the questions on a $R$. v. Parks $^{38}$ challenge for cause to ensure a more effective means of detecting unconscious racial bias. The standard Parks question asks whether the juror would be able to judge the evidence without bias, prejudice or partiality knowing that the accused is Black and, if applicable, the victim is White. In Gayle, the defence wanted to ask questions such as the following:

- Would you agree or disagree that some races are, by their nature, more violent than others?

- Would you agree or disagree that it is appropriate for Black people and White people to marry each other?

- Would you agree or disagree that there are too many Black people living in Toronto?

34 See Report of the Commission on Systemic Racism in the Ontario Criminal Justice System (Toronto: Queen's Printer, 1995), at iv-v, chapter 5. See also Gail Kellough \& Scot Wortley, "Remand for Plea: Bail Decisions and Plea Bargaining as Commensurate Decisions" (2002) 42 Brit. J. Crim. 186. The failure of the Supreme Court to address this data is criticized by Stuart, "Annotation" (2002) 4 C.R. (6th) 201.

35 The Commission specifically identified the reverse onus for drug offences contained in s. 515(6)(d) of the Criminal Code, R.S.C. 1985, c. C-46 as contributing to the disparity. It thus recommended that it be abolished. See Recommendation 5.8, Report of the Commission on Systemic Racism in the Ontario Criminal Justice System (Toronto: Queen's Printer, 1995), at 158. The reverse onus was upheld in $R$. v. Pearson, [1992] S.C.J. No. 99, [1992] 3 S.C.R. 665 (S.C.C.), but at that time neither the Court nor counsel had the benefit of the Commission's data or analysis.

36 [2001] S.C.J. No. 44, [2001] 2 S.C.R. 344 (S.C.C.)

37 [2001] O.J. No. 1559,154 C.C.C. (3d) 221 (Ont. C.A.).

38 [1993] O.J. No. 2157,84 C.C.C. (3d) 353 (Ont. C.A.). 
The argument was rejected. In fairness to the Court of Appeal, there was conflicting expert evidence at trial on the utility of the additional questions and the Court did recognize that:

It may well be that with the benefit of experience and the help of expert analysis on how best to uncover and assess racial bias, the challenge for cause process can be improved over time. ${ }^{39}$

Following Gayle, courts have refused to expand the Parks question. ${ }^{40}$

- $\quad$. v. Spence $e^{41}$ - In Spence, the victim was South Asian and the accused was Black. The African Canadian Legal Clinic ("ACLC") argued that the racial background of the victim should be part of the Parks challenge for cause question to ensure that racial partiality directed at the victim did not infect the trial process. The Court did not directly address the ACLC's argument. Instead, it focused on the issue from the perspective of the accused and on juror sympathy or empathy (i.e., whether a juror would convict because of a racebased sympathy for the victim) rather than the broader question of partiality. In other words, it did not consider that a juror could vote to acquit because of bias towards the victim and the societal interest in ensuring that verdicts are not racially tainted. The decision has enormous implications for the ability of parties to seek a challenge for cause in cases where it relates to a witness or the complainant. Indeed, Binnie J. seems to close the door with this comment:

The eventual logic of the defence argument, it seems, is that courts should take judicial notice of a "realistic possibility" of racial partiality in every case where the jurors, accused, complainant and witnesses are not all of the same race. ${ }^{42}$

- Peart v. Peel Regional Police Services Board ${ }^{43}$ - The African Canadian Legal Clinic argued for a reverse onus in racial profiling civil cases (i.e., placing the burden of proof on the police).

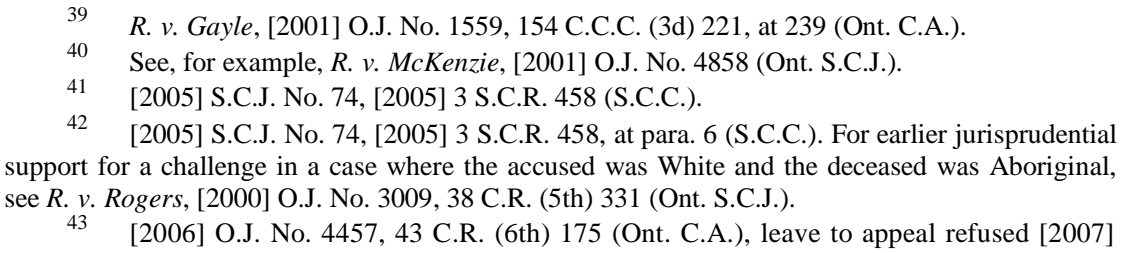


The argument was rejected. The Court appears to have left the issue open. As Justice Doherty observed:

... [the submission] is based on the argument that racial profiling is so common that where it is alleged, placing the burden on the police to disprove racial profiling is more likely to achieve an accurate result than is leaving the onus on the party alleging racial profiling. ...

The reality of racial profiling cannot be denied. There is no way of knowing how common the practice is in any given community. I am not prepared to accept that racial profiling is the rule rather than the exception where the police detain black men. I do not mean to suggest that I am satisfied that it is indeed the exception, but only that I do not know. ${ }^{44}$

Presumably if a better evidentiary record is put before the Court, the result might be different. ${ }^{45}$

- Charkaoui v. Canada (Citizenship and Immigration) ${ }^{46}$ - The Canadian Council on American-Islamic Relations ("CAIR-CAN") and Canadian Muslim Civil Liberties Association ("CMCLA") argued that the Court should factor in the racial profiling problem when interpreting the constitutionality of provisions enacted in the national security context. They further argued that the security certificate regime under the Immigration and Refugee Protection Act ${ }^{47}$ violates section 15(1) of the Charter because it is being applied in a discriminatory manner by targeting Arab and Muslim men and it is creating "a chilling effect among members of a disadvantaged group." 48 Although the Supreme Court did strike down the security certificate regime, it did not address the racial profiling or equality arguments.

Another troubling example of judicial reluctance to address racism in the justice system can be seen in $R$. v. Lines ${ }^{49}$ In that case the Crown brought a motion seeking a declaration that section 15(1) prevented the defence from exercising its peremptory challenges to remove Black

44 Peart v. Peel Regional Police Services Board, [2006] O.J. No. 4457, 43 C.R. (6th) 175, at 209 (Ont. C.A.), leave to appeal refused [2007] S.C.C.A. No. 10 (S.C.C.).

45 For an argument in favour of a reverse onus in criminal cases, see David M. Tanovich, The Colour of Justice: Policing Race in Canada (Toronto: Irwin Law, 2006), at 144-47.

46 [2007] S.C.J. No. 9, [2007] 1 S.C.R. 350 (S.C.C.).

47 S.C. 2001, c. 27, entered into force June 20, 2002.

48 Quoting from their factum, a copy of which is on file with the author.

49 [1993] O.J. No. 3284 (Ont. Gen. Div.). 
jurors. The case involved a White police officer charged with shooting a young Black male who was running away. ${ }^{50}$ The motion was dismissed. According to the trial judge:

In a criminal trial the accused is pitted against the state. In my opinion it is fanciful to suggest that in the selection of a jury he doffs his adversarial role and joins with the Crown in some sort of joint and concerted effort to empanel an independent and impartial tribunal. ...

For these reasons, the Crown motion to restrict the use of the peremptory challenge is dismissed. The Crown will be guided by its own conscience in its use of the peremptory challenge and so will the accused. $^{51}$

According to a media report of the trial, defence counsel, a senior member of the Ontario bar, used one of his peremptory challenges to exclude a Black hospital diet clerk from the jury after she had been found to be impartial by the two triers of fact. While no statement was made by Lines' lawyer as to why he felt that this juror was inappropriate, because none is given in this context, it is reasonable to infer racial discrimination was at least part of the reason. I say reasonable because (1) the case involved a racially charged incident of a police shooting; (2) the defence did not consent to the Crown motion to prevent him from exercising his peremptory challenges in a discriminatory fashion; and (3) of the seven peremptory challenges counsel used, four were used to exclude racialized jurors. ${ }^{52}$

A more obvious case of intentional discrimination occurred in the trial of James Houghton and Dwayne Johnston, two White men charged in the brutal death of Helen Betty Osbourne, a 19-year-old Aboriginal woman from The Pas, Manitoba. On November 13, 1971, Osbourne was stabbed with a screwdriver more than 50 times and her face smashed beyond recognition. It took 15 years before the RCMP finally charged three of the four men, even though the men were identified as the killers

50 Unlike challenges for cause, which require a showing of an "air of reality" of partiality, peremptory challenges under s. 634(1) of the Criminal Code, R.S.C. 1985, c. C-46 can be used as of right. The number of such challenges is dependent on the seriousness of the charge.

51 R. v. Lines, [1993] O.J. No. 3284, at paras. 26, 29 (Ont. Gen. Div.). In the United States, neither the prosecution nor the defence can use their peremptory challenges in a discriminatory fashion. See Georgia v. McCollum, 505 U.S. 42 (1992).

52 The jury ultimately consisted of 11 White jurors and one Asian juror. Lines was acquitted. 
by the police in $1972 .{ }^{53}$ Johnston was also represented by a senior member of the criminal bar in Manitoba. During jury selection, counsel used six of his peremptory challenges to exclude all of the Aboriginal jurors that had made it to the jury box. ${ }^{54}$ As a result, there were no Aboriginals on the jury. ${ }^{55}$ Defence counsel's conduct was specifically cited by the Manitoba Aboriginal Justice Inquiry as an instance of racism:

The systemic removal of potential Aboriginal jurors from the jury panel was motivated by their being Aboriginal persons. The jury selection process permitted racism to be applied. ${ }^{56}$

Even today, it remains unclear whether or not the Charter would prevent what occurred in these two cases, although it has been argued that the Rules of Professional Conduct now ethically prevent a lawyer from using peremptory challenges in this fashion. ${ }^{57}$ In an ironic twist of fate, Brian Trafford, one of the prosecutors in the Lines trial, was appointed to the bench and presided over the "Just Desserts" trial, another emotionally and racially charged trial in Toronto. This time it was the defence who brought a motion to limit the Crown from using its peremptory challenges in a discriminatory fashion. Justice Trafford held that he had the jurisdiction to regulate the use of peremptory challenges by the Crown and the defence to prevent discriminatory conduct $^{58}$

The issue arose again in $R . v$. Gayle ${ }^{59}$ a case involving a Black accused charged with shooting and killing a White police officer. During jury selection, the Crown used two of its peremptory challenges to exclude two Black jurors. The jury that tried the case had two racialized jurors but neither was African Canadian. On appeal, the accused argued that his section 11(f) and 15(1) Charter rights were violated by the Crown's conduct. He also argued that the section 15(1) rights of the two Black jurors had been violated. Relying on its earlier decision in $R$. v. Church

53 One of the three, Lee Colgan, was granted immunity in exchange for testifying against Houghton and Johnston. The fourth man, Norman Manger, was never charged.

54 Report of the Aboriginal Justice Inquiry of Manitoba: The Justice System and Aboriginal People (Volume 1) and The Deaths of Helen Betty Osbourne and John Joseph Harper (Volume 2) (Winnipeg, Queen's Printer, 1991), at 85-88.

55 Houghton was acquitted while Johnston was convicted.

56 Report of the Aboriginal Justice Inquiry of Manitoba: The Justice System and Aboriginal People (Volume 1) and The Deaths of Helen Betty Osbourne and John Joseph Harper (Volume 2) (Winnipeg, Queen's Printer, 1991), at 93-94.

See David M. Tanovich, "Law's Ambition and the Reconstruction of Role Morality in Canada" (2005) 28 Dal. L.J. 267, at 293-94.

$58 \quad$ See R. v. Brown, [1999] O.J. No. 4867 (Ont. Gen. Div.).

59 [2001] O.J. No. 1559, 154 C.C.C. (3d) 221 (Ont. C.A.). 
of Scientology of Toronto, ${ }^{60}$ the Court of Appeal held that the accused had no standing to vindicate the rights of the jurors. The Court also declined to decide whether his rights had been breached because the issue was raised on appeal for the first time and, in the Court's view, an insufficient evidentiary record existed.$^{61}$

What is more troubling perhaps is that the language used by the Court suggests that it only recognized a jurisdiction to review the exercise of race-based peremptory challenges because it was Crown conduct that was involved. Justice Sharpe, for the Court, held:

An important part of the jury selection process is the right of both the Crown and the defence to exercise peremptory challenges. The very essence of a peremptory challenge is that its exercise requires no justification or explanation. ...

$$
\cdots \cdots
$$

There is little authority on the extent to which a court can review the exercise of a peremptory challenge by the Crown. While I do not think the circumstances of the present call for this court's intervention, I would not want these reasons to be read as eliminating the possibility, as there may well be instances in which it would be appropriate for a court to do so. There are two important legal principles that lead me to that view. First is the well-established principle of our law that the Crown bears a particular responsibility in conducting a criminal prosecution ... It is not appropriate for Crown counsel to seek a conviction at all costs. ...

The second principle that constrains the discretionary powers of the Crown is that the Crown must exercise the discretion accorded to it in conformity to Charter principles and values. ... ${ }^{62}$

60 [1997] O.J. No. 1548, 116 C.C.C. (3d) 1 (Ont. C.A.).

61 It is not clear, however, what other evidence was necessary. Again, given the racially charged nature of the case, and the Crown's use of two of its peremptory challenges to remove the only two Black jurors who had come forward, discrimination was certainly a reasonable inference to draw in the circumstances, which should have been sufficient to warrant the quashing of Gayle's conviction. In R. v. Amos, [2007] O.J. No. 3732 (Ont. C.A.), the Court held that there was no Charter violation where the Crown used a peremptory challenge to remove the only Black juror.

62 R. v. Gayle, [2001] O.J. No. 1559, 154 C.C.C. (3d) 221, at 249-51 (Ont. C.A.). 


\section{Hostile Adjudication}

In a number of cases, trial judges have been or appeared hostile when asked to adjudicate a race issue. Sometimes the hostility can be implied from the reasoning employed by the Court to dismiss the argument. A good example of this is the number of challenge-for-cause cases that were brought following $R . v$. Parks ${ }^{63}$ in areas outside of Metropolitan Toronto. They were dismissed on the grounds that defence counsel had failed to establish that racism extended beyond the borders of Toronto. ${ }^{64}$ It took a sternly worded judgment from McMurtry C.J.O. in R. v. Wilson to stop this nonsense:

It is unrealistic and illogical to assume that anti-black attitudes stop at the borders of Metropolitan Toronto. ... The possibility therefore of anti-black racism taking root in communities outside of Metropolitan Toronto ... should be a matter of concern for the criminal justice system. ${ }^{65}$

Other times, the disdain of the trial judge can be implied from the manner in which he or she controls the proceedings. In R. v. Watson, for example, the Ontario Court of Appeal observed:

We have carefully considered the appellant's claim that the trial judge's interjections at trial compromised trial fairness by impeding the defence's ability to effectively cross-examine the police witnesses on critical areas of their testimony including, in particular, on the defence assertion that the activities of the police were motivated by racial profiling. We are satisfied, on a review of the transcripts as a whole, that the combined effect of the frequency and nature of the trial judge's interjections during the conduct of the trial created the appearance of an unfair trial. ${ }^{66}$

63 [1993] O.J. No. 2157, 84 C.C.C. (3d) 353 (Ont. C.A.).

64 See, for example, R. v. Ecclestone, [1996] O.J. No. 497 (Ont. Gen. Div.); R. v. Myers (September 15, 1995) (Ont. Gen. Div.) (unreported). This was not just occurring in Ontario. Courts in Quebec were using a similar rationale to stop the extension of $R$. v. Parks, [1993] O.J. No. 2157, 84 C.C.C. (3d) 353 (Ont. C.A.). See R. v. Cinous, [2000] J.Q. no 6, 143 C.C.C. (3d) 397 (Que. C.A.), revd [2002] S.C.J. No. 28, [2002] 2 S.C.R. 3 (S.C.C.); R. v. Mankwe, [1997] J.Q. no 4058, 12 C.R. (5th) 273 (Que. S.C.). Once Mankwe reached the Supreme Court, the Crown had conceded the point: [2001] S.C.J. No. 62, [2001] 3 S.C.R. 3 (S.C.C.). See further R. v. Drakes, [1998] B.C.J. No. 127, 122 C.C.C. (3d) 498 (B.C.C.A.). Another issue that arose in the aftermath of Parks in Ontario was whether the decision applied where the victim was Black. This was settled with the decision in $R . v$. Willis, [1994] O.J. No. 1059, 90 C.C.C. (3d) 350 (Ont. C.A.).

65 [1996] O.J. No. 1689, 107 C.C.C. (3d) 86, at para. 14 (Ont. C.A.).

66 [2004] O.J. No. 4921, 191 C.C.C. (3d) 144, at 148 (Ont. C.A.). 
In some cases, it is more direct. In R. v. Brown, ${ }^{67}$ the Ontario Court of Appeal held that the trial judge's conduct raised a reasonable apprehension of bias. That conduct included an extraordinary suggestion in his reasons for sentence that Brown apologize to the officer for raising racial profiling:

I should say as well that I do not know whether my tone this afternoon might have displayed my distaste for the matters that were raised during the course of the trial, but that really is not relevant to determining the sentence. I do not disagree with the officer's initial assessment of you. You dealt with him apparently in a polite and courteous way, and I had the impression when you were giving your evidence that you are that sort of person. So there is nothing inherently reprehensible about your conduct that I think should be treated as an aggravating factor when it comes to imposing sentence, which is not to say that it would not be nice if perhaps you might extend an apology to the officer because, I am satisfied, the allegations were completely unwarranted. But that is only my assessment. You are not required to share it and I will leave it to you to do what you think is right in that regard. ${ }^{68}$

These instances of judicial reluctance and hostility certainly tend to confirm the theory that the composition of the judiciary and inherent conservatism of judicial review are some of the biggest hurdles in using litigation as a political tool of change. There is no question that increasing the diversity of the bench is one of the most pressing issues facing the justice system and that it will have a big impact on increasing the cultural competence of the judiciary. As for judicial conservatism, while the cases discussed earlier are very troubling, it may still be premature to reach any conclusions given that our courts are not, generally speaking, being asked to develop critical race standards or adjudicate race cases with any regularity.

\section{The Sounds of Trial Silence}

With respect to litigation, there has been a large-scale failure of trial lawyers to raise race once critical race standards have been established by the courts. The most cogent evidence of this is the small number of racial profiling cases that have been litigated following the decision of the Ontario Court of Appeal in R. v. Brown ${ }^{69}$ despite the fact that there

\footnotetext{
67 [2003] O.J. No. 1251, 173 C.C.C. (3d) 23 (Ont. C.A.).

68 R. v. Brown, [2003] O.J. No. 1251 , 173 C.C.C. (3d) 23, at 53 (Ont. C.A.).

69 [2003] O.J. No. 1251, 173 C.C.C. (3d) 23 (Ont. C.A.)
} 
are likely hundreds of such cases each year. ${ }^{70}$ There are other examples as well. No one has, since racial profiling emerged as a live issue in Charter jurisprudence, challenged the legitimacy of $R$. v. Ladouceur, ${ }^{71}$ the case that has provided the police with a racial profiling writ of assistance. ${ }^{72}$ Nor has there been a post-Pearson challenge to the reverse onus for drug offences at bail hearings given the findings and recommendations of the Ontario Systemic Racism Commission. ${ }^{73}$

And there have been few attempts to apply R. v. Parks $^{74}$ outside of the challenge for cause process. Parks established a number of propositions about the nature of racial bias that are now capable of being judicially noted. They include:

Racism, and in particular anti-black racism, is a part of our community's psyche. A significant segment of our community holds overtly racist views. A much larger segment subconsciously operates on the basis of negative racial stereotypes. Furthermore, our institutions, including the criminal justice system, reflect and perpetuate those negative stereotypes. ... ${ }^{75}$

The criminal trial milieu may also accentuate the role of racial bias in the decision-making process. Anti-black attitudes may connect blacks with crime and acts of violence. A juror with such attitudes who hears evidence describing a black accused as a drug dealer involved in an act of violence may regard his attitudes as having been validated by the evidence. That juror may then readily give effect to his or her preconceived negative attitudes towards blacks without regard to the evidence and legal principles ... ${ }^{76}$

As Binnie J. observed in Spence, "Parks show[s] that a black accused has reason to fear that some members of the ... community may be wrongly influenced by the colour of his or her skin." ${ }^{77}$ A similar observation was made in $R$. v. Williams in relation to Aboriginals. Justice McLachlin, as she

\footnotetext{
70 See David M. Tanovich, "The Further Erasure of Race in Charter Cases" (2006) 38 C.R. (6th) 84 , at $87-89$.

$71 \quad$ [1990] S.C.J. No. 53, [1990] 1 S.C.R. 1257 (S.C.C.).

72 I say this because the decision held that the police can stop a vehicle at any time without any requirement of individualized suspicion. The police simply have to assert that the stop was to check for vehicle maintenance or to ensure that the driver was licensed and the car insured. See the discussion earlier at note 35 . [1993] O.J. No. 2157, 84 C.C.C. (3d) 353 (Ont. C.A.). [1993] O.J. No. 2157, 84 C.C.C. (3d) 353, at 369 (Ont. C.A.). [1993] O.J. No. 2157, 84 C.C.C. (3d) 353, at 372 (Ont. C.A.) R. v. Spence, [2005] S.C.J. No. 74, [2005] 3 S.C.R. 458, at para. 42 (S.C.C.).
} 
then was, for the Court held "[r]acism against aboriginals includes stereotypes that relate to credibility, worthiness and criminal propensity.",78

Two contexts where Parks $^{79}$ and Williams ${ }^{80}$ are very relevant include Crown motions to introduce bad character evidence and defence motions to limit the cross-examination of the accused on his or her criminal record otherwise known as a Corbett application. In other words, it is open for counsel to develop an argument that systemic racism and stereotyping is a relevant factor to take into account when assessing the admissibility of character evidence and criminal record in a case involving a racialized accused ${ }^{81}$ In other words, it is possible to argue for the creation of a "race shield" provision much like the rape shield provision that operates in sexual assault cases to prevent unwarranted and damaging stereotypes from infecting the criminal trial. ${ }^{82}$

Why are trial lawyers not raising race when it is appropriate to do so? While the perception of judicial hostility is an easy scapegoat for many lawyers ${ }^{83}$ I think that the real reason for the silence is as noted in "The Further Erasure of Race in Charter Cases":

[Race is] not being raised because some lawyers are not seeing the issue, while others are uncomfortable engaging in race talk before our courts. Other lawyers, who are aware of the issue, may shy away from raising race because they believe that they have a strong argument using traditional constitutional principles or because they are simply

\footnotetext{
78 [1998] S.C.J. No. 49, [1998] 1 S.C.R. 1128, at para. 58 (S.C.C.).

79 R. v. Parks, [1993] O.J. No. 2157, 84 C.C.C. (3d) 353 (Ont. C.A.).

$80 \quad$ R. v. Williams, [1998] S.C.J. No. 49, [1998] 1 S.C.R. 1128 (S.C.C.)

81 There have been a number of cases involving Black accused where the argument could have been made in support of the application to edit their criminal records. See R. v. Brand, [1995] O.J. No. 1342, 98 C.C.C. (3d) 477 (Ont. C.A.); R. v. Wilson, [2006] O.J. No. 2478, 210 C.C.C. (3d) 23 (Ont. C.A.); R. v. Brown, [2002] O.J. No. 2562, 166 C.C.C. (3d) 570 (Ont. C.A.); R. v. Thompson, [2000] O.J. No. 2270, 146 C.C.C. (3d) 128 (Ont. C.A.).

82 There is some academic support for a race shield provision. See Christine Chambers Goodman, "The Color of Our Character: Confronting the Racial Character of Rule 404(b) Evidence" (2007) 25 Law \& Inequality 1; Sheri Lynn Johnson, "Racial Imagery in Criminal Cases" (1993), 67 Tul. L. Rev. 1739, at 1740.

83 Even assuming that there is genuine fear, the perception of judicial hostility should never serve as a justification for not raising the argument. As a practical matter, it is unlikely that a judge who finds racial profiling arguments to be distasteful will exclude evidence, particularly guns, under s. 24(2) in cases involving racialized accused. The concern of defence counsel should, therefore, be in creating a record and preserving the client's right to raise the issue on appeal. A similar point was made by the Supreme Court in Van de Perre v. Edwards, [2001] S.C.J. No. 60, [2001] 2 S.C.R. 1014 (S.C.C.) in the context of raising race in a custody dispute.
} 
not sure of how to factor in race and racial profiling into a framework of analysis under sections 9 and 24 of the Charter. $^{84}$

With respect to "not seeing the issue", this occurs because, for the most part, Whites do not see themselves as a race or everyday conduct as the product of White privilege. As Professor Coker so aptly puts it:

The third problem for confronting white complacency (or encouragement) of race disparities in the criminal justice is the invisibility (to whites) of white privilege. Whites seldom think of themselves through the lens of race; whiteness is invisible to most whites. Rather, whites see themselves and other whites as individuals. Because they cannot see the privilege that protects them from police maltreatment and suspicion, they have difficulty believing that such treatment is not in some way invited or provoked when it happens to others. ${ }^{85}$

It should be pointed out, in fairness, that defence lawyers are not the only participants in the justice system who have difficulty in understanding or engaging in race talk. One need only recall the conduct of one of the lawyers from the Nova Scotia Department of Public Prosecutions who, in the mid-1990s, accused a Black judge in Halifax of racial bias for pointing out, in response to a Crown question suggesting that the police never lie, that systemic racism in policing is a problem in Halifax. ${ }^{86}$ And not to forget, of course, that six of the 13 appellate judges who heard the appeals of the case concluded that this reality check raised a reasonable apprehension of bias. ${ }^{87}$

84 David M. Tanovich, "The Further Erasure of Race in Charter Cases" (2006) 38 C.R. (6th) 84, at 93. A similar observation was made by my colleague Brian Etherington in 1994 when he noted that:

Several reports express concerns about the possibility of disadvantage being suffered by persons in minority groups accused in bail, plea-bargaining and trial processes as a consequence of prejudice, cultural insensitivity or unawareness by defence counsel.

See Brian Etherington, Review of Multiculturalism and Justice Issues: A Framework for Addressing Reform (Ottawa: Department of Justice Research Section, 1994), at 24. This is precisely why it is essential that cultural competence be part of a lawyer's continuing legal education and why there is now an ethical obligation for lawyers to be so competent. See the discussion in "The Further Erasure of Race in Charter Cases", at 91-93.

85 Donna Coker, "Foreword: Addressing the Real World of Racial Injustice in the Criminal Justice System" (2003) 93 J. Crim. L. \& Criminology 827, at 870. See also Clark D. Cunningham, "The Lawyer as Translator, Representation as Text: Towards an Ethnography of Legal Discourse" (1992) 77 Cornell L. Rev. 1298.

${ }_{86}$ See R. v. S. (R.D.), [1995] N.S.J. No. 184 (N.S.S.C.) and the discussion of the case in David M. Tanovich, The Colour of Justice: Policing Race in Canada (Toronto: Irwin Law, 2006), at $125-30$.

87 See R. v. S. (R.D.), [1997] S.C.J. No. 84, [1997] 3 S.C.R. 484 (S.C.C.) and R. v. S. (R.D.), [1995] N.S.J. No. 444, 102 C.C.C. (3d) 233 (N.S.C.A.). Some good did come out of the litigation 


\section{The Sounds of Appellate Silence}

On a number of occasions, appellate lawyers have also failed to raise the issue of race on appeal. For example, no argument was made in R. v. Law ${ }^{88}$ despite uncontradicted evidence from one of the officers that amounted to racial profiling. That evidence was summarized by Bastarache J. as follows:

Corporal Desroches worked for the Criminal Intelligence Unit of the Moncton Police Force; he had been suspicious of the appellants from shortly after the restaurant's opening. He testified that his suspicions of wrongdoing were not substantiated, but that he had "a gut feeling" that they were not submitting all their taxes and that he "didn't know what [he] was gonna to find". Prior to the break and enter, Corporal Desroches had copied down the licence plate numbers of several patrons' vehicles. He was keeping information in relation to a file named "Asian Crimes" and inquired with Revenue Canada as to whether the restaurant's taxes had been paid. He was told by Revenue Canada that there was nothing irregular about the restaurant's operations. ${ }^{89}$

In $L a w,{ }^{90}$ the accused, who operated a restaurant, were charged with an offence under the Excise Tax Act. ${ }^{91}$ A safe from the restaurant had been stolen and abandoned in a field. The police found it. It was Desroches who, after learning that the safe had been found, was given permission by the Crown to photocopy the documents found in the safe. He then contacted Revenue Canada and, based on the information contained therein, they searched the restaurant and discovered that the accused had not been remitting the required GST. The Court held that Desroches' conduct constituted an unreasonable search that violated section 8 of the

as a majority of the Supreme Court judges held that a judge can use social context evidence, like evidence of systemic racism, as a lens to assess the evidence and draw conclusions. As Doherty $\mathrm{J}$. held in R. v. Hamilton, [2004] O.J. No. 3252186 C.C.C. (3d) 129, at 168 (Ont. C.A.):

R. v. S. (R.D.) draws a distinction between findings of fact based exclusively on personal judicial experience and judicial perceptions of applicable social context, and findings of fact based on evidence viewed through the lens of personal judicial experience and social context. The latter is proper; the former is not.

See also Peart v. Peel Regional Police Services Board, [2006] O.J. No. 4457, 43 C.R. (6th) 175, at $189-90$ (Ont. C.A.), leave to appeal refused [2007] S.C.C.A. No. 10 (S.C.C.). The dispute in $S$. (R.D.) focused on whether there was evidence which the lens could be used to examine.

88 [2002] S.C.J. No. 10, [2002] 1 S.C.R. 227 (S.C.C.).

89 R. v. Law, [2002] S.C.J. No. 10, [2002] 1 S.C.R. 227, at para. 4 (S.C.C.).

90 R. v. Law, [2002] S.C.J. No. 10, [2002] 1 S.C.R. 227 (S.C.C.).

91 R.S.C. 1985 , c. E-15. 
Charter. While the Supreme Court upheld the trial judge's decision to exclude the evidence under section 24(2), a racial profiling argument would have given the Court its first opportunity to address the issue. ${ }^{92}$

While like trial lawyers, appellate lawyers are prone to "not seeing" the issue or are unsure of how to factor race into the legal mix, they face the additional hurdle of not having a record from which to work. In $R$. $v$. Clayton, for example, Doherty J. observed:

Counsel for Farmer also argued that the trial judge erred in not recognizing that the police were engaged in racial profiling when they stopped Farmer's vehicle. Counsel, who also acted for Farmer at the trial, apparently first appreciated that this was a case of racial profiling some time after the trial was over. Racial profiling was not an issue at trial. No questions or arguments were directed to that issue.

I can dispose of the racial profiling argument quickly. There is no basis in the trial record for this submission which, as indicated above, was made for the first time on appeal. It is unfair to those who are the target of this serious allegation to raise it for the first time on appeal. In addition, advancing a claim of racial profiling where it is so obviously devoid of merit tends to trivialize a matter of serious concern within the community. Not only was there no evidence of racial profiling, for the reasons I will set out, the police were wrong to ignore the information that the perpetrators were "black males" in deciding who to stop at their roadblock. ${ }^{93}$

Justice Doherty is undoubtedly correct that raising a claim of profiling for the first time on appeal (or at trial) with no merit is a serious matter. But it is not clear why an appellate court should not be entitled to draw

92 This aspect of the decision is discussed by Professor Boyle in "Annotation" (2002) 48 C.R. (5th) 201, at 202-203.

3 [2005] O.J. No. 1078, 194 C.C.C. (3d) 289, at 295-96 (Ont. C.A.), revd [2007] S.C.J. No. 32 (S.C.C.). On appeal, the Supreme Court also held that the racial background of the accused was relevant because the suspects were described as Black (see paras. 44, 47 (Abella J.) and 123-124 (Binnie J.)). While the Court appears to have come to the correct conclusion on this issue given the very unique circumstances of the case, the decision is troubling in that it did not alert lower courts to the dangers of using race as part of a suspect description, particularly in cases of roadblock type stops. See the discussion of this issue in David M. Tanovich, The Colour of Justice: Policing Race in Canada (Toronto: Irwin Law, 2006), at chapter 9. Moreover, Binnie J., in his concurring opinion (at para. 22), boldly takes judicial notice of the fact that “ ... the 911 caller must be presumed to be less error prone in dealing with a person's appearance, which calls for less specialized knowledge and less sophisticated powers of observation. The blockade, complete as it was, involved no more than a brief imposition on the time of motorists departing from the parking lot." This runs completely contrary to the body of evidence of the unreliability of race-based suspect descriptions. 
an inference of profiling where there is a strong circumstantial case. Since most profiling is unconscious, is there really any point in putting the suggestion to the officer? What can he or she reasonably be expected to say in response to the question $?^{94}$ Moreover, why would a situation like this be any different from when an appellate court impugns the conduct of a trial Crown or judge or witness without first giving them an opportunity to respond?

The recent case of $R$. v. Harris ${ }^{95}$ provides a good example of where racial profiling could have been raised on appeal for the first time. In Harris, the officer stopped a vehicle for a purported improper turn with Harris, an African Canadian, in the front passenger seat. ${ }^{96}$ The officer asked Harris for identification. While Harris was not wearing a seatbelt, the trial judge concluded, based on the officer's testimony, that the purpose behind the request for identification was to conduct a Canadian Police Information Centre ("CPIC") check. The check was to determine, in his words, "whether persons were on probation or bail, or whether they were under some "level of surveillance"". The officer testified that this was a routine practice.

When looked at with the proper social context lens of racial profiling, these facts cried out for a finding of racially biased policing. It is rare that the circumstantial evidence of heightened scrutiny will be stronger. The officer's testimony that he always asked passengers for identification in order to conduct a CPIC check during a routine traffic stop could reasonably have been rejected. It is simply not credible and not consistent with the conduct of a reasonable police officer. Alternatively, and even more troubling, is that it may in fact be true because the officer stops a disproportionately high number of racialized drivers. Either way, it was testimony that was not strong enough to rebut the circumstantial evidence,

94 In R. v. Ngo, [2006] M.J. No. 348, 39 C.R. (6th) 183, at 201 (Man. Q.B.), for example, the trial judge noted that "it would be rare indeed to have any other response" when commenting on the police officer's denial in cross-examination that he engaged in racial profiling. In Ngo, an application to access police records and training materials in an effort to establish a pattern was refused. On this issue, see also $R$. v. Khan, [2004] O.J. No. 3811, 13 M.V.R. (5th) 244 (Ont. S.C.J.); R. v. Fitch, [2006] S.J. No. 420, 39 C.R. (6th) 172 (Sask. C.A.). In an annotation to Fitch, Professor Quigley notes that "[t]here are sound reasons for placing some obligations on the defence to justify its application for disclosure of materials related to other investigations. ... However, it is also important that courts not impose an insurmountable barrier to such disclosure because of the risks of racial profiling and unjustified vehicle and pedestrian stops." See "Annotation" (2006) 39 C.R. (6th) 173.

[2007] O.J. No. 3185, 225 C.C.C. (3d) 193 (Ont. C.A.).

96 This fact was confirmed by appellate counsel. 
especially bearing in mind that the standard of proof is on a balance of probabilities.

While appellate lawyers may be constrained in alleging racial profiling for the first time on appeal in the absence of a fresh evidence application, they face no such impediment in raising race in other contexts for the first time on appeal. ${ }^{97}$ For example, since the issue of whether the accused was detained so as to trigger section 9 or section 10 of the Charter is an objective one and does not require the accused to testify, an appellate court can consider race as one contextual factor just as it could consider age or other relevant factors even where they are not relied upon below. ${ }^{98}$

Similarly, when assessing the seriousness of a Charter breach under section 24(2), an appellate court can consider, especially when it is deciding whether to exclude afresh, the extent to which the impugned conduct will have a disproportionate impact on racialized communities and the measures taken by the police to address systemic problems including racial profiling. This could be done even in the absence of a specific finding of racial profiling. ${ }^{99}$ It should be noted, however, that simply pointing out the disproportionate impact without also raising the sufficiency of the measures taken by the police to address the problem may not be enough. In R. v. Harris, ${ }^{100}$ for example, the Ontario Court of Appeal recognized that the disproportionate effects of over-policing felt by racialized communities is a relevant consideration in assessing the seriousness of the violation:

The use of the broad powers associated with Highway Traffic Act stops to routinely investigate passengers who have nothing to do with the concerns justifying those stops must have a significant cumulative, long-term, negative impact on the personal freedom enjoyed by those who find themselves subject to this kind of police conduct. While for persons in some segments of the community, these stops may be infrequent, this record suggests that for others the stops are an all too

97 Where there is nothing on the record to infer the accused's racial background, counsel could simply alert the Court with notice to the Crown. It is not as though this will be a contested fact.

${ }_{98}$ This could have been done in three recent cases from the Ontario Court of Appeal. See R. v. Grant, [2006] O.J. No. 2179,209 C.C.C. (3d) 250 (Ont. C.A.), leave to appeal allowed [2007] S.C.C.A. No. 99 (S.C.C.); R. v. Burke, [2006] O.J. No. 2185, 38 C.R. (6th) 104 (Ont. C.A.); R. v. B. (L.), [2007] O.J. No. 3290 (Ont. C.A.).

99 This argument is fleshed out in more detail in David M. Tanovich, "The Further Erasure of Race in Charter Cases" (2006) 38 C.R. (6th) 84, at 98-101. In a nutshell, the argument is that there should be no good faith finding where the police have failed to follow the recommendation of data collection by the Ontario Human Rights Commission in its 2005 Policy and Guidelines on Racism and Racial Profiling.

100 [2007] O.J. No. 3185, 225 C.C.C. (3d) 193 (Ont. C.A.). 
familiar part of their day-to-day routine. Viewed from the perspective of those who are most likely to find themselves stopped and questioned by police, I think this form of interrogation is anything but trivial. It seems to me at some point it must become provocative. ${ }^{101}$

However, the Court did not find that the violation in the case was serious enough to warrant exclusion.

Yet another relevant context is Charter appellate litigation that involves the creation of new standards because courts will, in deciding the breadth of the standard, take into account the extent to which it will ensure justice for all. In $R$. v. Belnavis, ${ }^{102}$ for example, a police officer searched the contents of a number of garbage bags containing clothes in the back seat of a vehicle he had purportedly stopped for speeding. The vehicle contained three Black women (Belnavis, the driver, and two passengers including Lawrence). Racial profiling was not argued at trial or on appeal. The Crown conceded that the search was unreasonable under section 8 because it was made in the absence of probable cause, but the Supreme Court did not exclude the evidence of the stolen clothing found in the bags under section 24(2). It further held that as a passenger, Lawrence had no standing to challenge the search of the car and, in the absence of any connection to the bags, standing to challenge that search either.

Nevertheless, La Forest J., in his dissenting opinion, was prepared to take race into account when determining how to approach the standing issue. He noted that:

In this case the majority's approach virtually eviscerates the right of a wide range of passengers in an automobile to be left alone by the police, and allows the police to importune even those considered to retain some element of privacy. I find the approach wholly inappropriate in a free society and quite simply disturbing in its general implications.

Moreover, the Court's understanding of the implications of the police action may be obscured by the fact that most cases that come before them relate to someone who has already been convicted. The courts have little "feel" for what this means to persons who have committed no wrong or any idea of the number of such people who may be harassed by the overly zealous elements in any police force. ...

\footnotetext{
101 R. v. Harris, [2007] O.J. No. 3185, 225 C.C.C. (3d) 193, at para. 63 (Ont. C.A.).

102 [1997] S.C.J. No. 81, [1997] 3 S.C.R. 341 (S.C.C.).
} 
[This case] has grave implications for equality in the application of the law. ... It does not prove but certainly does not detract from this thesis that the appellants in the present case are both members of a visible minority. ${ }^{103}$

When a court is establishing new Charter standards, even a White litigant can make a critical race argument. As Sopinka J. recognized in R. v. DeSousa:

It is clear that as the liberty interest of the appellant is ultimately at risk in this appeal, the appellant has the right to question the constitutional validity of the provision under which he is charged. This is the case even though the unconstitutional effects may not be directed at the appellant per se ... ${ }^{104}$

This is why in R. v. Ladouceur, ${ }^{105}$ Sopinka J., in his dissenting opinion on whether random vehicle stops constituted a reasonable limit under section 1 of the Charter, was able to point out that:

By contrast, the roving random stop would permit any individual officer to stop any vehicle, at any time, at any place. The decision may be based on any whim. Individual officers will have different reasons. Some may tend to stop younger drivers, others older cars, and so on. Indeed, as pointed out by Tarnopolsky J.A., racial considerations may be a factor too. ${ }^{106}$

(emphasis added)

And so, in R. v. Malmo-Levine, ${ }^{107}$ a case involving a constitutional challenge to the marijuana possession law, the lawyers and interveners could have relied on the social context evidence that the war on drugs has had a disproportionate impact on racialized communities in Canada in support of the gross disproportionality argument that was ultimately rejected by the Supreme Court. ${ }^{108}$

103 R. v. Ladouceur, [1997] S.C.J. No. 81, [1997] 3 S.C.R. 341, at paras. 50, 65, 66 (S.C.C.). Given what we now know about the scope of racial profiling in Canada, it is time for the Supreme Court to revisit its standing decision in R. v. Belnavis, [1997] S.C.J. No. 81, [1997] 3 S.C.R. 341 (S.C.C.).

104 [1992] S.C.J. No. 77, [1992] 2 S.C.R. 944, at 952-53 (S.C.C.).

105 [1990] S.C.J. No. 53, [1990] 1 S.C.R. 1257 (S.C.C.).

106 [1990] S.C.J. No. 53, [1990] 1 S.C.R. 1257, at 1267 (S.C.C.).

107 [2003] S.C.J. No. 79, [2003] 3 S.C.R. 571 (S.C.C.).

108 This social context evidence is discussed in David M. Tanovich, The Colour of Justice: Policing Race in Canada (Toronto: Irwin Law, 2006), at chapter 5. See also Marlow \& Tyler, "Pot Arrests Target Gangs, Says Chief" Toronto Star (10 July 2007) documenting the increased arrests in Toronto for marijuana possession and the increased "focus", as Chief Blair puts it, "in the communities where the street gangs operate ...". 
Appellate lawyers looking for empowerment can also now turn to a number of recent cases where the Supreme Court has explicitly adopted critical race standards in constitutional adjudication. In $R$. v. Golden, Iacobucci and Arbour JJ., for the majority, held in the context of determining the appropriate Charter standards for strip searches incident to arrest under section 8 :

The intervener African Canadian Legal Clinic (ACLC) agrees with the appellant that probable cause and a warrant requirement should be required for strip searches to be constitutional under s. 8 of the Charter. The ACLC says that given the negative stereotyping of African Canadians by police and the large number of African Canadians who are stopped and searched by police, a public process of obtaining a warrant is required to reduce the danger of racist stereotyping by individual police officers, who are more likely than a neutral arbiter to conclude that a strip search of a black person is appropriate. The intervener Aboriginal Legal Services of Toronto (ALST) also advocates a regime of prior authorization for strip searches ...

.. we believe it is important to note the submissions of the ACLC and the ALST that African Canadians and Aboriginal people are overrepresented in the criminal justice system and are therefore likely to represent a disproportionate number of those who are arrested by police and subjected to personal searches, including strip searches (Report of the Aboriginal Justice Inquiry of Manitoba (1991), Vol. 1, The Justice System and Aboriginal People, at p. 107; Cawsey Report, Justice on Trial: Report of the Task Force on the Criminal Justice System and its Impact on the Indian and Metis People of Alberta (1991), Vol. II, p. 7, recommendations 2.48 to 2.50; Royal Commission on Aboriginal Peoples, Bridging the Cultural Divide (1996), at pp. 33-39; Commission on Systemic Racism in the Ontario Criminal Justice System, Report of the Commission on Systemic Racism in the Ontario Criminal Justice System (1995)). As a result, it is necessary to develop an appropriate framework governing strip searches in order to prevent unnecessary and unjustified strip searches before they occur. ${ }^{109}$

In Golden, race was not raised as an issue at trial and yet this did not foreclose the approach the Court took to its constitutional analysis. The Supreme Court took a similar equality-oriented approach in Sauvé v.

109 [2001] S.C.J. No. 81, [2001] 3 S.C.R. 679, at paras. 81, 83 (S.C.C.). I was counsel for Ian Golden in the Supreme Court. While the Court did not impose a warrant requirement, it did impose very strict guidelines that had to be followed before a strip search could be conducted. 
Canada (Chief Electoral Officer) in finding that section 51(e) of the Canada Elections Act, ${ }^{110}$ which denies all prisoners serving a sentence of two years or more the right to vote, violates section 3 of the Charter which guarantees every citizen the right to vote. ${ }^{111}$

\section{CONCLUSION}

This refusal of judges to act and lack of race consciousness by lawyers are having a direct impact on the ability of the Charter to remedy racial injustice. We can see this by examining two of the bright spots: race-based challenges for cause and the recognition of the existence of racial profiling by our courts. With respect to challenges for cause, there is no question that $R$. v. Parks ${ }^{12}$ stands out as one of the most significant Charter race cases. The cases that followed such as $R$. v. Williams ${ }^{113}$ and $R$. v. Koh ${ }^{114}$ have established that Aboriginal and all racialized accused are entitled to challenge prospective jurors for racial bias as of right under section 638(1)(b) of the Criminal Code. ${ }^{115}$ But the utility of Parks and Williams has been limited by the failure of the courts to permit a more sophisticated manner of questioning. Judging the impartiality of a prospective juror on his or her yes or no answer to a question which simply asks whether the juror believes that he or she can be impartial in a case with a Black or Aboriginal accused is not sufficient. ${ }^{116}$ It is time to relitigate this issue. Similarly, to permit lawyers to use race-based peremptory challenges and not to give accused standing to argue the section 15(1) rights of prospective jurors is simply to close one's eyes and further enable racism in the justice system.

110 R.S.C. 1985, c. E-2 [repealed by S.C. 2000, c. 9, s. 576].

11 [2002] S.C.J. No. 66, [2002] 3 S.C.R. 519 (S.C.C.). As McLachlin C.J.C. held, for the majority (at para. 60), in assessing the proportionality prong of the $\mathrm{s} .1$ analysis:

The negative effects of s. 51(e) upon prisoners have a disproportionate impact on

Canada's already disadvantaged Aboriginal population, whose overrepresentation in prisons

reflects "a crisis in the Canadian criminal justice system": R. v. Gladue, [1999] 1 S.C.R.

688, at para. 64, per Cory and Iacobucci JJ.

112 [1993] O.J. No. 2157,84 C.C.C. (3d) 353 (Ont. C.A.).

113 [1998] S.C.J. No. 49, [1998] 1 S.C.R. 1128 (S.C.C.).

114 [1998] O.J. No. 5425, 131 C.C.C. (3d) 257 (Ont. C.A.).

115 R.S.C. 1985 , c. C-46.

116 There is also a more fundamental question of the competence of jurors to make impartiality determinations, especially since at the beginning of the process, the initial triers are not themselves prescreened. This is something that needs to be addressed by Parliament. 
With respect to racial profiling, while it is true that the recent decisions from our courts and human rights tribunals are significant, ${ }^{117}$ the standards they have imposed are having little effect, in part, because of other sections 8, 9 and 24(2) cases which limit their application. For example, section 9 is only triggered upon a detention and the courts have applied a narrow approach to street-level detentions with little consideration of the relevance of race on the issue of psychological detention. ${ }^{118}$ As the Supreme Court held in R. v. Mann, "... the police cannot be said to 'detain', within the meaning of ss. 9 and 10 of the Charter, every suspect they stop for purposes of identification, or even interview." ${ }^{\prime 19}$ Hopefully, the Court will reconsider its approach when it decides $R$. $v$. Grant. ${ }^{120}$ It would do well to consider the reasoned judgments in $R$. v. Griffiths $;{ }^{121}$ $R$. v. Pinto ${ }^{122}$ and, R. v. Savory,${ }^{123}$ all of which employed a critical race perspective on this issue. These cases recognize that it is unreasonable to conclude that an African Canadian or Aboriginal would feel free to walk away from the police given the history of police violence and racial profiling in their communities.

Moreover, section 8 can only be advanced where the individual has standing (i.e., reasonable expectation of privacy) and again courts have adopted a narrow approach to this issue as we saw in $R$. v. Belnavis. ${ }^{124}$

117 See R. v. Brown, [2003] O.J. No. 1251, 173 C.C.C. (3d) 23 (Ont. C.A.); Peart v. Peel Regional Police Services Board, [2006] O.J. No. 4457, 43 C.R. (6th) 175 (Ont. C.A.), leave to appeal refused [2007] S.C.C.A. No. 10 (S.C.C.); R. v. Campbell, [2005] Q.J. no 394 (C.Q.); Nassiah v. Peel Regional Police Services Board, [2007] O.H.R.T.D. No. 14 (O.H.R.T.).

118 The issue of race and detention has been explored in a number of previous pieces. See David M. Tanovich, "The Further Erasure of Race in Charter Cases" (2006) 38 C.R. (6th) 84, at 93-96; David M. Tanovich, The Colour of Justice: Policing Race in Canada (Toronto: Irwin Law, 2006), at 147-49.

119 [2004] S.C.J. No. 49, [2004] 3 S.C.R. 59, at para. 19 (S.C.C.). Mann was followed in R. v. B. (L.), [2007] O.J. No. 3290. See also R. v. Harris, [2007] O.J. No. 3185, 225 C.C.C. (3d) 193 (Ont. C.A.), where the Court of Appeal left open the question of whether a passenger in a vehicle is detained when the car is pulled over by the police. Although (at para. 19) the Court did hold (in response to the Crown argument):

The trial judge doubted the correctness of the submission. So do I. It is inconsistent with trial decisions in this province: e.g. see $R$. v. Pinto, [2003] O.J. No. 5172 (S.C.J.); $R$. v.

J.R.M., [2005] O.J. No. 4708 (C.J.). It also runs against the unanimous recent decision of the

United States Supreme Court in Brendlin v. California (2007) 551 U.S. [127 S. Ct. 2400].

120 [2006] O.J. No. 2179, 209 C.C.C. (3d) 250 (Ont. C.A.), leave to appeal allowed [2007] S.C.C.A. No. 99 (S.C.C.).

121 [2003] O.J. No. 1544, 11 C.R. (6th) 136 (Ont. C.J.).

122 [2003] O.J. No. 5172, 113 C.R.R. (2d) 140 (Ont. S.C.J.).

123 [2002] O.J. No. 2715, 95 C.R.R. (2d) 261 (Ont. C.J.).

124 [1997] S.C.J. No. 81, [1997] 3 S.C.R. 341 (S.C.C.). 
This issue is again before the Supreme Court in $R$. v. Brown $n^{125}$ in the context of the use of dogs to sniff for drugs. This is a critical issue because the use of dogs and other tactics such as securing consent to search by Operation Pipeline/Jetway/Convoy, a RCMP drug interdiction program, are having a disproportionate impact on racialized individuals. ${ }^{126}$

And finally, as noted earlier, under section 24(2), the failure to raise race has too easily allowed courts to rely on good faith and the seriousness of gun and drug offences in not excluding evidence obtained in violation of the Charter. This is what is happening in the Ontario Court of Appeal in cases like R. v. Grant, ${ }^{127} R$. v. Harris ${ }^{128}$ and now R. v. B. (L.). ${ }^{129}$ As Moldaver J. put it in R. v. B. (L.):

This case involves a loaded handgun in the possession of a student on school property. Conduct of that nature is unacceptable without exception. It is something that Canadians will not tolerate. It conjures up images of horror and anguish the likes of which few could have imagined twenty-five years ago when the Charter first came to being. Sadly, in recent times, such images have become all too common children left dead and dying; families overcome by grief and sorrow; communities left reeling in shock and disbelief.

That is the backdrop of this case and in my view, it provides the context within which the conduct of the police should be measured ... ${ }^{130}$

While the effects of gun violence are indeed tragic, so too are the consequences of racial profiling. That too was a backdrop of the case, one that was not raised and so not considered by the Court. It is interesting that the Court was prepared to take account of the effects of gun violence, even though there was no evidence before it, but not of racial profiling in Toronto because "no such allegations have been made".

And so, as these examples illustrate, engaging in race talk and developing critical race standards are critical because colour-blind due

125 [2006] S.C.C.A. No. 323 (S.C.C.), on appeal from [2006] A.J. No. 755, 210 C.C.C. (3d) 317 (Alta. C.A.).

126 Although it is difficult to track cases since race is rarely mentioned in judgments, I was able to ascertain (by name or by contacting counsel) that of 25 reported QL cases involving Operation Pipeline/Jetway/Convoy, 14 involve racialized individuals. The link between Operation Pipeline and racial profiling is discussed in David M. Tanovich, The Colour of Justice: Policing Race in Canada (Toronto: Irwin Law, 2006), at 91-94.

127 [2006] O.J. No. 2179,209 C.C.C. (3d) 250 (Ont. C.A.), leave to appeal allowed [2007] S.C.C.A. No. 99 (S.C.C.).

128 [2007] O.J. No. 3185, 225 C.C.C. (3d) 193 (Ont. C.A.).

129 [2007] O.J. No. 3290 (Ont. C.A.).

130 [2007] O.J. No. 3290, at paras. 80-81 (Ont. C.A.). 
process standards are working disproportionately to the disadvantage of racialized groups. That is the future of Charter litigation in this country. There is no question that what lies ahead will be difficult. There is every reason, however, to be optimistic. Lawyers and judges are committed to the pursuit of justice and with a greater understanding of what needs to be done and commitment to getting it done, we may begin to see significant change. 